\title{
EFFECTS OF DIET COMPOSITION ON CONSUMPTION, LIVE BODY WEIGHT AND LIFE SPAN OF WORKER HONEY BEES (Apis mellifera L.)
}

\author{
OSKAY, D. \\ Tekirdă̆ Namık Kemal University, Agriculture Faculty, Department of Agricultural \\ Biotechnology, 59030 Tekirda $\breve{g}$, Turkey \\ (e-mail: doskay@nku.edu.tr; phone: +90-282-250-2292; fax:+90-282-250-9929) \\ (Received 22 $2^{\text {nd }}$ Apr 2021; accepted 20 ${ }^{\text {th }}$ Sep 2021)
}

\begin{abstract}
Due to current threats such as climate change, emerging diseases, and agricultural chemical use, honey bees are struggling to obtain adequate uncontaminated nectar and pollen for survival. Under these conditions, beekeepers feed their colonies with pollen and honey substitutes. In this study, several experimental diets were examined and compared with pollen and honey substitutes used by the beekeepers. The effects of the diets on consumption, live body weight and lifespan of groups of adult worker honey bees were investigated under laboratory conditions. "Natural-like" diet was used as control. Solid food with different amounts of protein and enzymatically prepared liquid food, enzymatically prepared liquid food with added caffeine, colored non-enzymatically prepared liquid food were tested. Pollen substitute protein levels were 0.4 to $10 \%$. Solid food with low protein diet was consumed less, and resulted in low live body weight and low survival in comparison to control and higher protein amounts. Bees fed with enzymatically prepared liquid food with added caffeine group showed more activity but did not attain significantly higher survival ratio than bees fed only enzymatically prepared liquid food. This study discusses role of protein content and food preparation in the management of honey bee colonies.
\end{abstract}

Keywords: nutrition, substitutes, protein, sugar, beekeeping

\section{Introduction}

Nutrition has a significant impact on animal health, disease resistance, and ability to survive. Honey bee nutrition is a popular issue in beekeeping on a global scale (Pudasaini et al., 2020). Honey provides energy for honey bees (Apis mellifera L.), while pollen provides protein and is required for larval and adult stage growth.

Climate change, diseases, agricultural chemicals and habitation loss affect honey bees negatively (Brown et al., 2016). Currently, honey bees have difficulty to finding enough uncontaminated nectar and pollen (Hladun et al., 2012, 2015; Silici et al., 2016). This is essential for their survival. Even when pollen is available, not all pollen provides an adequate quantity of nutrition for colony development (Pernal and Currie, 2000). Furthermore, honey bee foraging opportunities are limited throughout the year due to environmental factors such as temperature, humidity, light intensity, solar irradiation values, wind, rain, and flower patches (Farrar, 1934; Burrill and Dietz, 1981; Winston, 1987). Under these conditions, beekeepers feed their colonies with pollen and honey substitutes. In order to grow honey bee colony population, rearing brood, queens, drones, successful overwintering, and increase honey production, supplementary diets are needed (Herbert, 1992; Goodwin et al., 1994; Koç and Karacaoğlu, 2004). Several studies have been conducted in order to develop an ideal supplemental protein diet for honey bees that is healthy, extremely wealthy in required nutrients, and easily accepted. Previous studies have examined the effects of protein- and carbohydrate-rich supplement foods on colony development, lifespan, brood, honey, production performance, wax construction and honey bee biology (Herbert et al., 1977, 1992; Doull, 1980; Winston et al., 1983; 
Cremonez et al., 1998; Mattila and Otis, 2006; Dastouri and Maheri-Sis, 2007; Cappelari et al., 2009; Basualdo et al., 2013, 2014; Kumar and Agrawal, 2014; Gemeda, 2014; Pande et al., 2015; Frias et al., 2016; Paiva et al., 2016; Almaida-Dias et al., 2018; Mohammad et al., 2020; Adgaba et al., 2020; Mahbob et al., 2021). Manning et al. (2007) demonstrated that soy protein shortens the life span of honey bees, implying that soy proteins are less appealing to honey them. Therefore, soy protein has not used in this study.

Danihlik et al. (2018) examined changes in immune system characteristics in bees given various pollen diets. Their results on the significance of protein content in the bee diet have practical consequences for rethinking the value of protein supplementation in the sugar-based diet given to bee colonies, as well as its effect on bee and colony health and successful wintering capability. Scientific study is ongoing to find out the impact of compounds that provide critical nutrition to honey bees. Vrabie et al. (2019) supplemented honey bee colonies with whey protein and observed an increase in brood development of 13.1-14.5 percent and acacia honey yield of 24.7-44.8 percent.

Scientists all around the globe have developed several substitute meal recipes for bees based on the nutritional content of honey and pollen, acceptability, digestibility, and affordability of materials. This may assist to keep all colony characteristics stable enough to take full benefit of the next nectar flow season. However, a globally recognized standard balanced diet for commercial beekeeping is still needed (Paray et al., 2021).

Three honey and three pollen substitutes were used under laboratory conditions to better understand the effects of different kinds of honey and pollen substitutes on bees, as well to determine their impact on adult bee live body weight, feed consumption and life span. The live body weight difference across age groups with different honey, pollen substitutions, and effect of phagostimulants such as caffeine are examined in this study for the first time.

\section{Material and Method}

\section{Rearing conditions and modalities of treatment}

Capped brood combs with emerging bees were collected in May 2016 from 20 honey bee colonies led by sister queens at Tekirdag Namik Kemal University apiaries (Tekirdag, Turkey). These brood combs were incubated overnight at hive temperatures and humidity $\left(35^{\circ} \mathrm{C}, 75 \%\right.$ humidity, and no light) to simulate the hive environment for providing 1 day old bees. Bees that had just emerged were carefully brushed into a wide plastic basin and mixed.

The size of the cages was $14 \mathrm{~cm} \times 13 \mathrm{~cm} \times 8.3 \mathrm{~cm}$ and the volume was $1.5 \mathrm{~L}$. A wide section of the cages was glued to the floor, and 4 ventilation holes were opened, up to a diameter of $2 \mathrm{~cm}$. and a height of $4 \mathrm{~cm}$. above the floor. The top of the cage also had an opening of $4 \mathrm{~cm}$ diameter. Side ventilation holes of the cage were covered with wiremesh (fly screen) and silicone. 100 individual bees were placed inside the transparent plastic cages $(14 \times 13 \times 8.3 \mathrm{~cm})$ and returned to the incubator $\left(75 \%\right.$ humidity and $35^{\circ} \mathrm{C}$ temperature); as in Evans et al. (2009).

Each cage represented one of 6 treatment groups. 100 one-day old worker bees placed in each group cage. All food was provided to bees in a free-choice feeding system in Eppendorf culture vials $(15 \mathrm{~mL})$ with small holes that allow bees to enter in tubes. The feed vials were replaced every three days. 
A "natural-like" diet was utilized in the experiment. Honey and fresh pollen were gathered from University apiaries honey bee colonies. Honey and fresh pollen were stored in a glass jar. Honey was maintained at ambient temperature throughout the experiment, whereas pollen was stored at $-18{ }^{\circ} \mathrm{C}$.

Two different pollen substitute diets were experienced: two containing higher levels of crude protein and another one with a lower protein content. $10 \%$ protein pollen substitute was a mixture of inactive bread yeast extract powder, powdered beet sugar, inverted sugar syrup (70\% sugar, 30\% water), sunflower honey and sunflower seed oil. $0.4 \%$ pollen substitute was a commercial food containing soybean flour.

Three different honey substitute diets were tested for the experiment. Inverted sugar syrup (enzymatically prepared liquid food) was produced by dissolving beet sugar in water and by addition of invertase enzyme. The inverted sugar syrup was mixed and stored at $40^{\circ} \mathrm{C}$ temperature for 36 hours. It was fed to caged bees within one week of production. Caffeine powder was supplied from Sigma-Aldrich Co. LLC. $1 \mathrm{mM}$ caffeine concentration was used for enzymatically prepared liquid food for the added caffeine group (Wright et al., 2013). Colored non-enzymatically prepared liquid food was acquired commercially.

A: "natural-like" diet used as control (honey and pollen).

B: solid food with $0.4 \%$ protein (pollen substitute).

C: solid food with $10 \%$ protein (pollen substitute).

D: Enzymatically prepared liquid food (sugar syrup).

E. Enzymatically prepared liquid food with some caffeine (sugar syrup).

F: Colored non-Enzymatically prepared liquid food (sugar syrup).

The quantity of consumed food was measured every 3 days, before each fill up, by weighing the solid and liquid foods remaining in the feeder vials, and as compared to the weight of the full feeder at the start. The alteration in milligrams was transformed to microliters ( $1 \mu \mathrm{L}=1.22 \mathrm{mg}$ of sugar syrup) and divided by the number of surviving bees (Renzi et al., 2016). The total amount of solid and liquid food consumed was calculated after 24 days.

Because the live body weight parametry had not previously been studied in honey bee worker bee feeding research, the solid food with $10 \%$ protein feed group (C) was chosen to represent the protein feed group for comparison with the control group when designing the experimental groups, while enzymatically prepared liquid food (D) and colored nonenzymatically prepared liquid food $(\mathrm{F})$ were chosen to represent the protein feed group for comparison with the control group. One, twelve, twenty-four days old live bees collected from cages were placed in different size of tubes, weighed with a precision scale and placed back in their cages alive. Ten live worker bees from each group were chosen at random for live body weight measurements. Every day, dead bees were gathered and counted from the cages.

\section{Data analyses}

The impact of nutritional treatments on solids, liquids, food consumption, and body weight was evaluated using two-way ANOVA. For the six diet applications, the KaplanMeier survival test was used for the life span of honey bees (Kleinbaum and Mitchel, 1996; Wang et al., 2014). Graphpad Prism 6.0 software (GraphPad software, San Diego, USA) was used to conduct statistical analysis. 


\section{Results}

\section{Live body weight}

The effects of the dietary treatments on live body weight performance are shown in Figure 1. When the experiment started the mean live body weights in treatment groups "natural-like" diet used as control (A), solid food with $10 \%$ protein (C), enzymatically prepared liquid food (D), colored non-enzymatically prepared liquid food (F) at one day of age was, $89.77 \pm 1.71 \mathrm{mg}, 90.66 \pm 1.58 \mathrm{mg}, 90.22 \pm 1.39 \mathrm{mg}$, and $89.77 \pm 1.39 \mathrm{mg}$, respectively. There were no significant differences among groups $\left(\mathrm{F}_{1.24}=2.16, \mathrm{P}>0.05\right)$. The mean live body weights in treatment groups $\mathrm{A}, \mathrm{C}, \mathrm{D}$ and $\mathrm{F}$ at 12 days of age were, $136.40 \pm 14.75 \mathrm{mg}, 128.60 \pm 16.29 \mathrm{mg}, 106.60 \pm 16.06 \mathrm{mg}$, and $99.80 \pm 15.80 \mathrm{mg}$. There was a significant difference among groups $(\mathrm{P}<0.05)$. There was not a statistical difference between "natural -like" diet used as control (A) and solid food with $10 \%$ protein (C) $(\mathrm{P}>0.05)$. There was not a statistical difference between enzymatically prepared liquid food (D), colored non-enzymatically prepared liquid food $(\mathrm{F})(\mathrm{P}>0.05)$. There was a significant difference between protein $(\mathrm{A}$ and $\mathrm{C})$ and carbohydrate diet groups (D and F) $(\mathrm{P}<0.05)$.

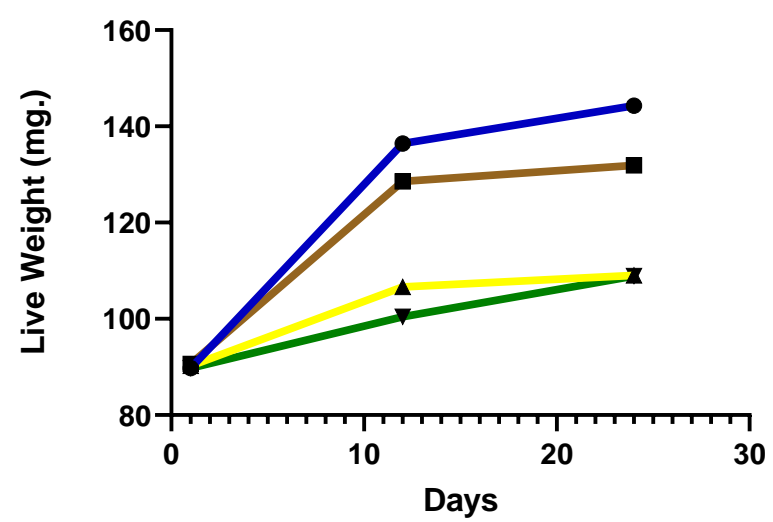

$\rightarrow$ Natural -like" diet

Solid food with $10 \%$ protein

Enzymatically prepared liquid food

Colored

$\rightarrow$ non-Enzymatically prepared liquid food

Figure 1. Live body weight (mg) of caged worker bees fed with different diets

The mean live body weights in treatment groups A, C, D, F at 24 days of age were, $144.33 \pm 9.34 \mathrm{mg}, 131.90 \pm 23.64 \mathrm{mg}, 109 \pm 4.82 \mathrm{mg}$, and $108.88 \pm 18.78 \mathrm{mg}$. There was not a statistical difference between "natural -like" diet used as control (A) and solid food with $10 \%$ protein $(\mathrm{C})(\mathrm{P}>0.05)$. In addition, there wasn't a statistical difference between enzymatically prepared liquid food (D), colored non-enzymatically prepared liquid food (F) $(\mathrm{P}>0.05)$. A significant difference was found between protein (A and $\mathrm{C}$ ) and carbohydrate diet groups $(\mathrm{D}$ and $\mathrm{F})$ diet groups $(\mathrm{P}<0.05)$. Highest live body weight was the control group. An inverted syrup without enzyme group was lowest live weight.

\section{Solid food consumption quantity}

The effects of the dietary treatments on solid food consumption by bees in groups "natural-like" diet (A), solid food with $0.4 \%$ protein (B), and solid food with $10 \%$ protein (C) are shown in Figure 2. Solid food consumption was measured every 3 days through 21 days. Mean of daily solid food consumption in treatment groups A, C and B during the three weeks of the experiment were, $20.61 \pm 10.33 \mu \mathrm{g}, 14.42 \pm 11.45 \mu \mathrm{g}$, and $0 \pm 0$, respectively. 


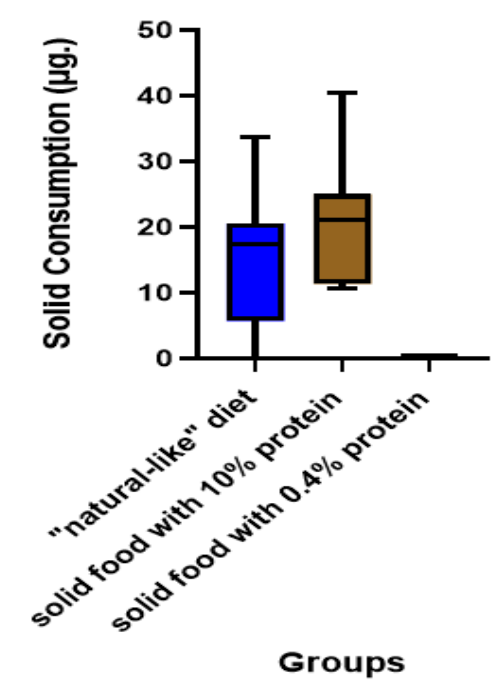

Figure 2. Daily solid food consumption ( $\mu \mathrm{g})$ per bee at the 21 days of caged worker bees fed with different diets

Highest consumption was for "natural-like" diet among the solids but there is no significant difference between "natural-like" diet (A) and solid food with $10 \%$ protein groups $(\mathrm{C})\left(\mathrm{F}_{1.21}=9.85, \mathrm{P}>0.05\right)$. There was no solid feed consumption at solid food with $0.4 \%$ protein group (B). Bees consumed only enzymatically prepared liquid food.

\section{Liquid food consumption quantities}

The effects of the dietary treatments on liquid consumption food groups, "natural-like" diet used as control (A), enzymatically prepared liquid food (D), enzymatically prepared liquid food with some caffeine (E), colored non-Enzymatically prepared liquid food (F) (A, D, E and F) performance is shown in Figure 3. Liquid food consumption was measured every 3 days during the 21 days. Mean of daily liquid food consumption in treatment groups $\mathrm{A}, \mathrm{D}, \mathrm{F}$ and $\mathrm{E}$ through the three weeks of the experiment were, $26.47 \pm 14.99 \mu \mathrm{L}, 37.50 \pm 15.86 \mu \mathrm{L}, 29.87 \pm 18.41 \mu \mathrm{L}$ and $41.96 \pm 15.34 \mu \mathrm{L}$ respectively. Diet quality had no effect on daily liquid food consumption from the $1^{\text {st }}$ to the $21^{\text {st }}$ day of treatment $\left(\mathrm{F}_{1.21}=1.32, \mathrm{P}>0.05\right)$. There was also no significant relation among food consumption amounts. Highest consumption was enzymatically prepared liquid food with some caffeine (E) among the liquid foods. Lowest consumption was honey among the liquid foods.

\section{The life span of honey bee}

The mean of life span days in treatment groups "natural-like" diet used as control (A), solid food with $0.4 \%$ protein (B), solid food with $10 \%$ protein $(\mathrm{C})$, enzymatically prepared liquid food (D), enzymatically prepared liquid food with some caffeine (E), colored non-enzymatically prepared liquid food (F) was $24.6 \pm 1.38,23.25 \pm 2.60,29.01 \pm 1.86$, $22.56 \pm 1.98,23.28 \pm 3.14$ and $19.92 \pm 3.07$, respectively. There were significant differences among groups $(\mathrm{P}<0.001)$. Bees fed with solid food with $10 \%$ protein $(\mathrm{C})$ showed the best survival. There was no significant difference between bees fed "natural-like" $\operatorname{diet}(\mathrm{A})$ and bees fed with solid food with $10 \%$ protein $(\mathrm{C})(\mathrm{P}>0.05)$. There was no significant difference among enzymatically prepared liquid food (D), solid food with $0.4 \%$ protein 
(B) and enzymatically prepared liquid food with some caffeine (E) $(\mathrm{P}>0.05)$. Colored non-enzymatically prepared liquid food $(\mathrm{F})$ showed the lowest survival that was significantly different than other groups $(\mathrm{P}<0.001)$. Bees fed with higher protein ratio groups showed significantly different survival results than bees fed with only syrups in terms of average lifespan $\left(\mathrm{X}^{2}=44.59, \mathrm{P}<0.001\right)$ (Figure 4).

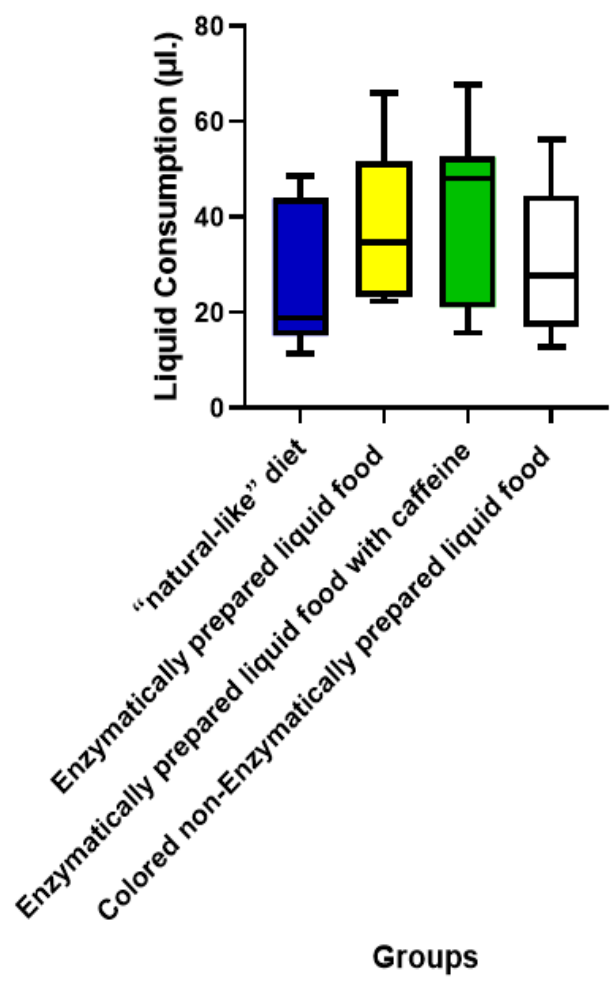

Figure 3. Daily Liquid food consumption $(\mu L)$ of caged worker bees fed with different liquid diets
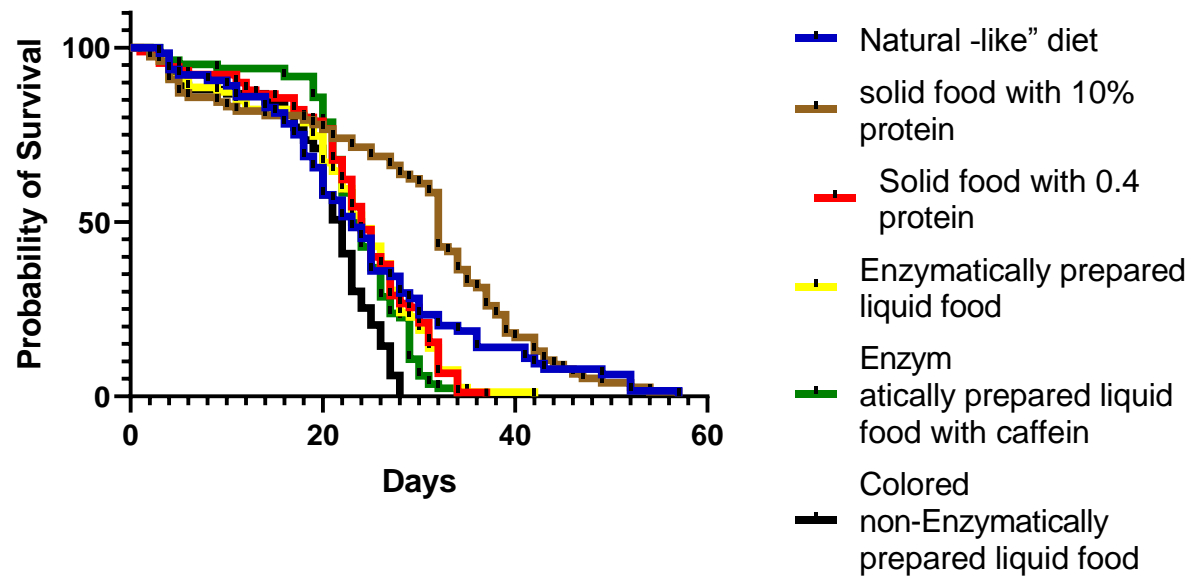

Figure 4. Survival of newly emerged bees caged and fed a variety of diets under incubator settings. Foods were controlled, "natural-like" diet used as control (A), solid food with $0.4 \%$ protein $(B)$, solid food with $10 \%$ protein $(C)$, enzymatically prepared liquid food $(D)$, enzymatically prepared liquid food with some caffeine $(E)$, colored non-enzymatically prepared liquid food $(F)$ 


\section{Discussion}

The results obtained in this study, with respect to live body weight, food consumption, and life span, are in agreement with the pollen and honey substitute effects reported by Dastouri and Maheri-Sis (2007) and Basualdo et al. (2013, 2014). Kumar et al. (2014) remarked that bee body weight is not efficient method of calculating the protein rank of bees provided with high level-protein-content pollen (HLCP) and low level-proteincontent pollen (LLCP). Content of HLCP and LLCP protein ratio were $29 \%$ and $10 \%$. In this study, content of high level protein diets were \%10, "natural -like" diet. When it was compared live body weight with liquid food without protein and solid food with $10 \%$ protein groups it was a significant difference between groups. It means that live body weight parameter would use depend of protein ratio level of diet.

The study's key result is that bees fed pollen and a $10 \%$ pollen substitute had the highest survival rate, whereas bees fed only inverted sugar syrup had the shortest lifespan.

The current study's findings contradict those of Pirk et al. (2010), who demonstrated that bees fed carbohydrate survived better than bees fed pollen substituted with sugar. In their study, they have used casein as a protein source. Additionally, Altaye et al. (2010) demonstrated that while casein diets increased survival and Feed-Bee® diets decreased it, royal jelly diets increased ovarian activation and casein diets decreased it.

The findings confirm that a high-protein diet has a positive effect on live body weight in bees sampled on the $12^{\text {th }}$ and $24^{\text {th }}$ days, which correlates to the age of maximum body growth in worker bees.

Gregorc et al. (2019) conducted a 9-day surviver test on bees fed in cages with various pollen substitute ratios. According to the research, there were extremely fast bee mortality in the groups given $50 \%$ and $40 \%$ pollen substitute feed. As a result, they suggested that high protein diets should be avoided in adult bees.

Bees foraging at a feeder containing $1 \mathrm{M}$ sucrose with caffeine made more visits than bees foraging at a feeder containing an equivalent molarity sucrose without caffeine, according to Couvillon et al. (2015). Also, caffeine increases the tendency and rate of recurrence of individual bee waggle dancing. In this experiment, enzymatically prepared liquid food with some caffeine (E) bees didn't any significant differences than other liquid groups about live body weight, consumption and surviving. While changing their food in the cages, the bees in the enzymatically prepared liquid food with some caffeine group move and run more than the bees in the other groups. These motions, however, have not been quantified.

\section{Conclusion}

Present results demonstrate that $\% 10$ protein ratio can be used in feed patties for feeding colonies in spring and autumn season for colony nutrition management.

Supplemental feeding is generally used by beekeepers to sustain colony maintenance strategy to promote up their honey bee colonies when nectar and pollen sources are scarce in nature or in agriculturally plants cultivated, but the dietary basis of protein and carbohydrate supplement issue has not been studied sufficiently. In this research, prepared pollen (Group C) and honey (Group D and E) substitutes gave rational results based on honey bee ecology and physiology. Given that climate change, urbanization, agricultural chemicals, diseases, and pests will all have a detrimental impact on honey bees in the future, greater emphasis should be given to nutritional research. There is a need for substitute food studies that incorporate vitamins, minerals, lipids, prebiotics, and 
probiotics in addition to the carbohydrate and protein sources utilized in bee substitute diets.

The impact of naturally occurring secondary metabolites, such as caffeine, on honey bee behavior and metabolism should be investigated.

Acknowledgements. The author would like to thank Y1lmaz Berk Koru, Gizem Sönmez Oskay, and Mustafa Degermenci for their assistance in gathering the data.

\section{REFERENCES}

[1] Adgaba, N., Al-Ghamdi, A., Tadesse, Y., Mohammed, S. E. A., Al-Attal, Y. (2020): BroodRearing Enhancing Potential of Manually Packed Pollen Feeding in Comparison with Pollen and Pollen Supplements in Patty Forms. - Journal of Apicultural Science 64(2): 189-198.

[2] Almaida-Dias, J. M., Morais, M. M., Francoy, T. M., Pereira, R. A., Turcatto, A. P., De Jong, D. (2018): Fermentation of a pollen substitute diet with bee bread microorganisms increases diet consumption and hemolymph protein levels of honey bees (Hymenoptera: Apidae). - Sociobiology 65(4): 760-765. doi: 10.13102/ sociobiology.v65i4.3293.

[3] Altaye, S. Z., Pirk, C. W., Crewe, R. M., Nicolson, S. W. (2010): Convergence of carbohydrate-biased intake targets in caged worker honeybees fed different protein sources. - Journal of Experimental Biology 213(19): 3311-3318.

[4] Basualdo, M., Barragan, S., Vanagas, L., Garcia, C., Solana, H., Rodriguez, E., Bedascarrasbure, E. (2013): Conversion of high and low pollen protein diets into protein in worker honey bees (Hymenoptera: Apidae). - Journal of Economic Entomology 106: 1553-1558. doi: 10.1603/EC12466.

[5] Basualdo, M., Barragan, S., Antunez, K. (2014): Bee bread increases honeybee haemolymph protein and promote better survival despite causing higher Nosema ceranae abundance in honeybees. - Environmental Microbiology Reports 6: 396-400. doi: 10.1111/1758-2229.12169.

[6] Brown, M. J., Dicks, L. V., Paxton, R. J., Baldock, K. C., Barron, A. B., Chauzat, M. P., Li, J. (2016): A horizon scan of future threats and opportunities for pollinators and pollination. - Peer J 4: e2249.

[7] Burrill, R. M., Dietz, A. (1981): The response of honey bees to variations in solar radiation and temperature. - Apidologie 12: 319-328.

[8] Cappelari, F. A., Turcatto, A. P., Morais, M. M., De Jong, D. (2009): Africanized honey bees more efficiently convert protein diets into hemolymph protein than do Carniolan bees (Apis mellifera carnica). - Genetics and Molecular Research 8: 1245-1249. doi: 10.4238/vol8-4gmr628.

[9] Couvillon, M. J., Al Toufailia, H., Butterfield, T. M., Schrell, F., Ratnieks, F. L., Schürch, R. (2015): Caffeinated forage tricks honeybees into increasing foraging and recruitment behaviors. - Current Biology 25(21): 2815-2818.

[10] Cremonez, T. M., De Jong, D., Bitondi, M. M. G. (1998): Quantification of hemolymph proteins as a fast method for testing protein diets for honey bees (Hymenoptera: Apidae). - J. Econ. Entomol. 91: 1284-1289.

[11] Danihlík, J., Škrabišová, M., Lenobel, R., Šebela, M., Omar, E., Petřivalský, M., Brodschneider, R. (2018): Does the pollen diet influence the production and expression of antimicrobial peptides in individual honey bees? - Insects 9(3): 79.

[12] Dastouri, M. R., Maheri-Sis, N. (2007): The effect of replacement feeding of some protein sources with pollen on honey bee population and colony performance. - J. Anim. Vet. Adv. 6: $1258-1261$. 
[13] Doull, K. M. (1980): Relationships between consumption of a pollen supplement, honey production and brood rearing in colonies of honeybees Apis mellifera L. II. - Apidologie 11: 367-374.

[14] Evans, D. J., Chen, P. Y., Prisco, G., Pettis, J., Williams, V. (2009): Bee cups: single-use cages for honey bee experiments. - Journal of Apicultural Research and Bee World 48(4): 300-302.

[15] Farrar, C. L. (1934): Bees must have pollen. - Glean. Bee Cult. 62: 276-278.

[16] Frias, B. E. D., Barbosa, C. D., Lourenço, A. P. (2016): Pollen nutrition in honey bees (Apis mellifera): impact on adult health. - Apidologie 47(1): 15-25.

[17] Gemeda, T. K. (2014): Testing of effect of dearth period supplementary feeding of honeybee (Apis mellifera) on brood development and honey production. - International Journal of Advance Research 2(11): 319-324.

[18] Goodwin, R. M., Ten Houten, A., Perry, J. H. (1994): Effect of feeding pollen substitutes to honey bee colonies used for kiwifruit pollination and honey production. - New Zealand J. Crop. Hort. 22: 459-462.

[19] Gregorc, A., Sampson, B., Knight, P. R., Adamczyk, J. (2019): Diet quality affects honey bee (Hymenoptera: Apidae) mortality under laboratory conditions. - Journal of Apicultural Research 58(4): 492-493.

[20] Herbert, E. W., Shimanuki, H., Caron, D. (1977): Optimum protein levels required by honey bees (Hymenoptera: Apidae) to initiate and maintain brood rearing. - Apidologie 8: 141-146. doi: 10.1051/apido:19770204.

[21] Herbert, E. W. (1992): Honey bee nutrition. - In: Graham, J. M. (ed.) The hive and the honey bee. - Dadant and Sons, Hamilton, IL. pp. 197-233.

[22] Hladun, K. R., Smith, B. H., Mustard, J. A., Morton, R. R., Trumble, J. T. (2012): Selenium toxicity to honey bee (Apis mellifera L.) pollinators: effects on behaviors and survival. PloS one 7(4): e34137.

[23] Hladun, K. R., Parker, D. R., Trumble, J. T. (2015): Cadmium, copper, and lead accumulation and bioconcentration in the vegetative and reproductive organs of Raphanus sativus: implications for plant performance and pollination. - Journal of Chemical Ecology 41(4): 386-395.

[24] Kleinbaum, D. G., Mitchel, K. (1996): Statistics for Biology and Health (survival analysis, second edition). - Springer science + Business Media, Inc.

[25] Koç, A. U., Karacaoglu, M. (2004): Effects of rearing season on the quality of queen honeybees (Apis mellifera L.) raised under the conditions of Aegean Region. - Mellifera 4(7): 34-37.

[26] Kumar, R., Agrawal, O. P. (2014): Comparative performance of honeybee colonies fed with artificial diets in Gwalior and Panchkula region. - Journal of Entomology and Zoology Studies 2(4): 104-107.

[27] Mahbob, M., Adahm, M., Mohamed, A. R., Rania-Qurash, S. (2021): A fermented Pollen Substitute Diet Affects Wax Construction by Honey Bee Workers (Apies mellifera L.). Egyptian Academic Journal of Biological Sciences A, Entomology 14(2): 1-11.

[28] Manning, R., Rutkay, A., Eaton, L., Dell, B. (2007): Lipid-enhanced pollen and lipidreduced flour diets and their effect on the longevity of honey bees (Apis mellifera L.). Australian Journal of Entomology 46(3): 251-257.

[29] Mattila, H. R., Otis, G. W. (2006): The effects of pollen availability during larval development on the behavior and physiology of spring-reared honey bee workers. Apidologie 37: 533-546.

[30] Mohammad, R. H. S., Sari, M., Tahmasbi, G., Chaji, M. (2020): The effects of different levels of protein and silymarin on the population growth and Hypopharyngeal gland surface of honey bee workers (Apis mellifera meda). - Biotechnology in Animal Husbandry 36(3): 341-358. 
[31] Paiva, J. P. L. M., Paiva, H. M., Esposito, E., Morais, M. M. (2016): On the effects of artificial feeding on bee colony dynamics: a mathematical model. - Plos One 11: e0167054. doi: $10.1371 /$ journal.pone.0167054.

[32] Pande, R., Karnatak, A. K., Pande, N. (2015): Development of nectar supplements for death period management of honeybees (Apis mellifera L.) colonies in foothills of Shivalik range of Himalayan. - The Bioscan 10(4): 1599-1603.

[33] Paray, B. A., Kumari, I., Hajam, Y. A., Sharma, B., Kumar, R., Albeshr, M. F., Khan, J. M. (2021): Honeybee nutrition and pollen substitutes: A review. - Saudi Journal of Biological Sciences 28(1): 1167.

[34] Pernal, S. F., Currie, R. W. (2000): Pollen quality of fresh and 1-year-old single pollen diets for worker honey bees (Apis mellifera L.). - Apidologie 31: 387-409.

[35] Pirk, C. W., Boodhoo, C., Human, H., Nicolson, S. W. (2010): The importance of protein type and protein to carbohydrate ratio for survival and ovarian activation of caged honeybees (Apis mellifera scutellata). - Apidologie 41(1): 62-72.

[36] Pudasaini, R., Dhital, B., Chaudhary, S. (2020): Nutritional requirement and its role on honeybee: a review. - Journal of Agriculture and Natural Resources 3(2): 321-334.

[37] Renzi, M. T., Rodríguez-Gasol, N., Medrzycki, P., Porrini, C., Martini, A., Burgio, G., Maini, S., Sgolastra, F. (2016): Combined effect of pollen quality and thiamethoxam on hypopharyngeal gland development and protein content in Apis mellifera. - Apidologie 47: 779.

[38] Silici, S., Uluozlu, O. D., Tuzen, M., Soylak, M. (2016): Honeybees and honey as monitors for heavy metal contamination near thermal power plants in Mugla, Turkey. - Toxicology and Industrial Health 32(3): 507-516.

[39] Vrabie, V., Derjanschi, V., Ciochină, V., Vrabie, E. (2019): The use of whey for honey bee feeding and obtaining of proteincarbohydrate bee feed. - In: Scientific Papers Series D, Animal Science 62: 105-110.

[40] Wang, H., Zhang, S. W., Zeng, Z. J., Yan, W. Y. (2014): Nutrition affects longevity and gene expression in honey bee (Apis mellifera L.) workers. - Apidologie 45(5): 618-625.

[41] Winston, M. L. (1987): The Biology of the Honey Bees. - Harvard University Press, London, UK.

[42] Winston, M. L., Chalmers, W. T., Lee, P. C. (1983): Effects of two pollen substitutes on brood mortality and length of adult life in the honey bee. - Journal of Apicultural Research 22: 49-52.

[43] Wright, G. A., Baker, D. D., Palmer, M. J., Stabler, D., Mustard, J. A., Power, E. F., Stevenson, P. C. (2013): Caffeine in floral nectar enhances a pollinator's memory of reward. - Science 339(6124): 1202-1204. 